\title{
Front Matter: Volume 7481
}

, "Front Matter: Volume 7481," Proc. SPIE 7481, Electro-Optical and Infrared Systems: Technology and Applications VI, 748101 (8 October 2009); doi: 10.1117/12.848797

SPIE. Event: SPIE Security + Defence, 2009, Berlin, Germany 


\section{PROCEEDINGS OF SPIE}

\section{Electro-Optical and Infrared Systems: Technology and Applications VI}

David A. Huckridge

Reinhard R. Ebert

Editors

31 August-3 September 2009

Berlin, Germany

Sponsored by

SPIE Europe

Cooperating Organisations

SPIE

Electro Magnetic Remote Sensing Defence Technology Centre (United Kingdom)

OPTHER

Published by

SPIE

Volume 7481 
The papers included in this volume were part of the technical conference cited on the cover and title page. Papers were selected and subject to review by the editors and conference program committee. Some conference presentations may not be available for publication. The papers published in these proceedings reflect the work and thoughts of the authors and are published herein as submitted. The publisher is not responsible for the validity of the information or for any outcomes resulting from reliance thereon.

Please use the following format to cite material from this book:

Author(s), "Title of Paper," in Electro-Optical and Infrared Systems: Technology and Applications VI, edited by David A. Huckridge, Reinhard R. Ebert, Proceedings of SPIE Vol. 7481 (SPIE, Bellingham, WA, 2009) Article CID Number.

ISSN 0277-786X

ISBN 9780819477873

Published by

SPIE

P.O. Box 10, Bellingham, Washington 98227-0010 USA

Telephone +1 3606763290 (Pacific Time) · Fax +1 3606471445

SPIE.org

Copyright (C) 2009, Society of Photo-Optical Instrumentation Engineers

Copying of material in this book for internal or personal use, or for the internal or personal use of specific clients, beyond the fair use provisions granted by the U.S. Copyright Law is authorized by SPIE subject to payment of copying fees. The Transactional Reporting Service base fee for this volume is $\$ 18.00$ per article (or portion thereof), which should be paid directly to the Copyright Clearance Center (CCC), 222 Rosewood Drive, Danvers, MA 01923. Payment may also be made electronically through CCC Online at copyright.com. Other copying for republication, resale, advertising or promotion, or any form of systematic or multiple reproduction of any material in this book is prohibited except with permission in writing from the publisher. The CCC fee code is 0277-786X/09/ $\$ 18.00$.

Printed in the United States of America.

Publication of record for individual papers is online in the SPIE Digital Library.

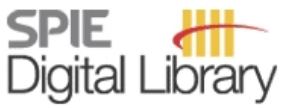

SPIEDigitalLibrary.org

Paper Numbering: Proceedings of SPIE follow an e-First publication model, with papers published first online and then in print and on CD-ROM. Papers are published as they are submitted and meet publication criteria. A unique, consistent, permanent citation identifier (CID) number is assigned to each article at the time of the first publication. Utilization of CIDs allows articles to be fully citable as soon they are published online, and connects the same identifier to all online, print, and electronic versions of the publication. SPIE uses a six-digit CID article numbering system in which:

- The first four digits correspond to the SPIE volume number.

- The last two digits indicate publication order within the volume using a Base 36 numbering system employing both numerals and letters. These two-number sets start with 00, 01, 02, 03, 04, $05,06,07,08,09,0 A, 0 B \ldots 0 Z$, followed by 10-1Z, 20-2Z, etc.

The CID number appears on each page of the manuscript. The complete citation is used on the first page, and an abbreviated version on subsequent pages. Numbers in the index correspond to the last two digits of the six-digit CID number. 


\title{
Contents
}

\author{
vii Conference Committee \\ ix Joint research for tomorrow's security and defence (Plenary Paper) [7483-31] \\ R. Krug, The Federal Ministry of Defence (Germany)
}

\section{SESSION 1 SENSOR PROCESSING AND SCENE MODELING}

748102 Model-based object recognition in range imagery (Invited Paper) [7481-01]

W. Armbruster, FGAN-FOM (Germany)

748103 A framework for the development and assessment of target classification algorithms [7481-02]

R. Hansford, M. Nicholas, QinetiQ Ltd. (United Kingdom)

748104 Approximate non-parametric feature extraction applied to classification system data [7481-04]

K. Dorn, S. Gadaleta, C. Altinigneli, EADS Deutschland GmbH (Germany)

748105 Assisted interpretation of infrastructure facilities from aerial imagery [7481-05]

A. Baver, Fraunhofer Institute for Information and Data Processing (Germany)

748106 Thermal scene analysis via finite element model and finite difference time domain numerical solution of the electromagnetic wave propagation in the short wave and long wave infrared bandarch [7481-06]

A. Albertoni, BFI Optilas (Italy)

748107 pcSitoS: a new tool for image-based IR system simulation [7481-07]

H.-J. Greif, A. R. Weiss, W. Wittenstein, FGAN-FOM (Germany)

\section{SESSION 2A SPECTRAL AND MULTIBAND SENSORS I}

748108 A new imaging FTIR spectroradiometer [7481-08]

L. Moreau, C. Roy, C. Vallières, L. Levesque, M.-A. Soucy, ABB Inc. (Canada)

7481 OA Ultraviolet through infrared imager performance testing [7481-10]

J. A. Mazzetta, S. D. Scopatz, Electro Optical Industries, Inc. (United States)

$7481 \mathrm{OB}$ Improved target detection by IR dual-band image fusion [7481-11]

U. Adomeit, R. Ebert, FGAN-FOM (Germany) 
7481 OC Application of heterogeneous multiple camera system with panoramic capabilities in a harbor environment [7481-12]

P. B. W. Schwering, H. A. Lensen, S. P. van den Broek, R. J. M. den Hollander, W. van der Mark, H. Bouma, R. A. W. Kemp, TNO Defence, Security and Safety (Netherlands)

7481 OD Multispectral system for perimeter protection of stationary and moving objects [7481-13] M. Szustakowski, W. M. Ciurapinski, M. Zyczkowski, N. Palka, M. Kastek, R. Dulski, G. Bieszczad, T. Sosnowski, Military Univ. of Technology (Poland)

\section{SESSION 3 DETECTORS}

$7481 \mathrm{OE} \quad$ Advanced III/V quantum-structure devices for high performance infrared focal plane arrays (Invited Paper) [7481-14]

R. Rehm, M. Walther, J. Schmitz, F. Rutz, J. Fleissner, Fraunhofer-Institut für Angewandte Festkörperphysik (Germany); R. Scheibner, J. Ziegler, AIM Infrarot-Module GmbH (Germany)

7481 OF Latest developments in MCT for next generation of infrared staring arrays [7481-16] M. Vuillermet, F. Pistone, Y. Reibel, SOFRADIR (France)

$7481 \mathrm{OH} \quad$ Activation and evaluation of GaN photocathodes [7481-18] Y. Qian, B. Chang, J. Qiao, Y. Zhang, R. Fu, Y. Qiu, Nanjing Univ. of Science \& Technology (China)

7481 ol Novel technology for polymer-based microbolometers [7481-19] A. Nocke, M. Wolf, H. Budzier, K.-F. Arndt, G. Gerlach, Technische Univ. Dresden (Germany)

7481 OJ Uncooled amorphous silicon IRFPA for high performance and high volume applications [7481-20]

D. Pochic, A. Durand, J. L. Tissot, A. Crastes, M. Vilain, O. Legras, S. Tinnes, C. Minassian, P. Robert, ULIS (France)

\section{SESSION 4 SENSORS AND RELATED TECHNOLOGIES I}

7481 OL Flexible $640 \times 480$ pixel infrared camera module for fast prototyping [7481-23] A. Bergeron, L. Le Noc, B. Tremblay, F. Lagacé, L. Mercier, F. Duchesne, L. Marchese, J. Lambert, M. Jacob, M. Morissette, H. Jerominek, INO (Canada)

$7481 \mathrm{OM} \quad$ Modelling a crime scene in 3D and adding thermal information [7481-24] M. van lersel, H. Veerman, W. van der Mark, TNO Defence, Security and Safety (Netherlands)

$74810 \mathrm{~N}$ A technique for ghosting artifacts removal in scene-based methods for non-uniformity correction in IR systems [7481-25]

A. Rossi, M. Diani, G. Corsini, Univ. of Pisa (Italy)

748100 Method of detectors offset correction in thermovision camera with uncooled microbolometric focal plane array [7481-26]

G. Bieszczad, T. Orżanowski, T. Sosnowski, M. Kastek, Military Univ. of Technology (Poland) 
7481 OP Pyroelectric sensors and classification algorithms for border / perimeter security (Invited Paper) [7481-27]

E. L. Jacobs, S. Chari, C. Halford, The Univ. of Memphis (United States); H. McClellan, EOIR Technologies, Inc. (United States)

$74810 Q$ Controllable time dependent and dual band emission infrared source to test missile warning systems in-flight: system characterization [7481-28]

D. Cabib, L. Davidzon, A. Gil, Cl Systems Ltd. (Israel)

7481 OR Optimizing the design of electro-optical micro-satellite imagers for ship detection using a real-time simulator [7481-29]

F. D. Lapierre, A. Borghgraef, M. Vandewal, Royal Belgian Military Academy (Belgium)

7481 OS Development of a real time multiple target, multi camera tracker for civil security applications [7481-30]

H. Åkerlund, SAAB Dynamics AB (Sweden)

SESSION 5 SENSORS AND RELATED TECHNOLOGIES II

7481 OT Optical limiting performance of nanoparticles in liquid and solid media (Invited Paper) [7481-31]

S. Dengler, G. Ritt, B. Eberle, FGAN-FOM (Germany)

7481 oU Protection of optical systems against laser radiation [7481-32]

G. Ritt, S. Dengler, B. Eberle, FGAN-FOM (Germany)

7481 OV MTF measurement of infrared optical systems [7481-33]

A. Lengwenus, P. Erichsen, Trioptics GmbH (Germany)

7481 0X Spectral matching factors between low-light-level and infrared fusion optoelectronic detector and objects [7481-35]

L. Liu, Y. Fan, B. Chang, Nanjing Univ. of Science \& Technology (China)

\section{POSTER SESSION}

7481 OY Contribution of generation-recombination processes at inner interface of MBE-grown $\mathrm{Hg}_{1-\mathrm{x}} \mathrm{Cd}_{\mathrm{x}} \mathrm{Te}$ heterostucture to dark current of small active area photodiode [7481-36] G. V. Chekanova, FSUE ALPHA (Russian Federation); A. A. Drugova, V. Kholodnov, IRE Russian Academy of Sciences (Russian Federation); M. S. Nikitin, FSUE ALPHA (Russian Federation)

748110 Contribution to the study of night-time driving devices with thermal cameras and EMCCD [7481-38]

C. A. Spulber, O. V. C. Borcan, Pro Optica S.A. (Romania)

748111 Data fusion concept in multispectral system for perimeter protection of stationary and moving objects [7481-39]

W. Ciurapiński, R. Dulski, M. Kastek, M. Szustakowski, G. Bieszczad, M. Życzkowski,

P. Trzaskawka, M. Piszczek, Military Univ. of Technology (Poland)

748112 Validating temporal response models for an uncooled LWIR camera [7481-40]

M. M. Adams, S. I. Wilson, QinetiQ Ltd. (United Kingdom) 
748113 Measurement of sniper infrared signatures [7481-41]

M. Kastek, R. Dulski, P. Trzaskawka, G. Bieszczad, Military Univ. of Technology (Poland)

748116 Mutispectral image fusion for target detection [7481-44]

M. Leviner, M. Maltz, Ben-Gurion Univ. of the Negev (Israel)

Author Index 


\title{
Conference Committee
}

\author{
Symposium Chairs \\ David H. Titterton, Defence Science and Technology Laboratory \\ (United Kingdom) \\ Reinhard R. Ebert, Forschungsgesellschaft für Angewandte \\ Naturwissenschaften e.V. (Germany) \\ Conference Chairs
}

David A. Huckridge, QinetiQ Ltd. (United Kingdom)

Reinhard R. Ebert, Forschungsgesellschaft für Angewandte

Naturwissenschaften e.V. (Germany)

Program Committee

Christopher C. Alexay, Chris Alexay Optical Design (United States)

Jan Y. Andersson, Acreo AB (Sweden)

Rainer Breiter, AlM Infrarot-Module GmbH (Germany)

Gordon A. Cain, Octec Ltd. (United Kingdom)

David J. Clarke, SELEX GALILEO (United Kingdom)

Stefania De Vito, SELEX GALILEO (Italy)

Peter N. Dennis, QinetiQ Ltd. (United Kingdom)

Per S. W. Fredin, Saab Bofors Dynamics AB (Sweden)

Norman S. Kopeika, Ben-Gurion University of the Negev (Israel)

José M. López-Alonso, Universidad Complutense de Madrid (Spain)

John F. Parsons, Thales Optronics Ltd. (United Kingdom)

Stanley R. Rotman, Ben-Gurion University of the Negev (Israel)

Christopher W. Slinger, QinetiQ Ltd. (United Kingdom)

\section{Session Chairs}

1 Sensor Processing and Scene Modeling

Reinhard R. Ebert, FGAN-FOM (Germany)

David A. Huckridge, QinetiQ Ltd. (United Kingdom)

2A Spectral and Multiband Sensors I

Reinhard R. Ebert, FGAN-FOM (Germany)

David A. Huckridge, QinetiQ Ltd. (United Kingdom)

2B Spectral and Multiband Sensors II

Reinhard R. Ebert, FGAN-FOM (Germany)

David A. Huckridge, QinetiQ Ltd. (United Kingdom) 
Detectors

David J. Clarke, SELEX GALILEO (United Kingdom)

Rainer Breiter, AIM INFRAROT-MODULE GmbH (Germany)

4 Sensors and Related Technologies I

Reinhard R. Ebert, FGAN-FOM (Germany)

David A. Huckridge, QinetiQ Ltd. (United Kingdom)

5 Sensors and Related Technologies II

Reinhard R. Ebert, FGAN-FOM (Germany)

David A. Huckridge, QinetiQ Ltd. (United Kingdom)

Poster Session 